\title{
Cynolebias parnaibensis, a new seasonal killifish from the Caatinga, Parnaíba River basin, northeastern Brazil, with notes on sound producing courtship behavior (Cyprinodontiformes: Rivulidae)
}

\author{
Wilson J. E. M. Costa ${ }^{1}$, Telton P. A. Ramos ${ }^{2}$ Luisa C. Alexandre ${ }^{1}$ \\ and Robson T. C. Ramos ${ }^{2}$
}

Cynolebias parnaibensis from the Canindé River drainage, Parnaíba River basin, northeastern Brazil, is described. It is considered to be a member of a clade endemic to the Caatinga. The clade is diagnosed, e.g., by a series of structural modifications of the pharyngeal jaw apparatus, which is related to the sound production exhibited by males during courtship behavior. The courtship sound of C. parnaibensis consists of a single pulse named as thump (duration 0.031-0.133s; interthump intervals $0.020-8.319 \mathrm{~s}$; dominant frequency $70.3-93.8 \mathrm{~Hz}$ ). The new species is distinguished from all other congeners by a combination of 27-31 neuromasts around eye, 29-33 supraorbital neuromasts, 16-18 dorsal-fin rays and 19 anal-fin rays in males, 28-31 caudal-fin rays, 33-36 scales in the longitudinal series, 3+10 gill-rakers in the first branchial arch, absence of second pharyngobranchial teeth, absence of contact organs on the flank scales, 34-35 vertebrae, absence of teeth on vomer, and presence of transverse series of scales on the anal-fin base.

Cynolebias parnaibensis, da drenagem do rio Canindé, bacia do rio Parnaíba, nordeste do Brasil, é descrita. Ela é considerada um membro de um clado endêmico da Caatinga. O clado é diagnosticado, e.g., por uma série de modificações estruturais do aparato mandibular faringiano, que está relacionado à produção de som exibida por machos durante o comportamento de corte. O som de corte de C. parnaibensis consiste de um único pulso denominado como thump (duração 0,031-0,133s; intervalos entre thumps 0,020-8,319s; frequência dominante 70,3-93,8 Hz). A nova espécie se distingue de todos os outros congêneres por uma combinação de 27-31 neuromastos em torno do olho, 29-33 neuromastos supraorbitais, 16-18 raios na nadadeira dorsal e 19 raios na nadadeira anal em machos, 28-31 raios na nadadeira caudal, 33-36 escamas na série longitudinal, 3+10 rastros branquiais no primeiro arco branquial, ausência de dentes no segundo faringobranquial, ausência de órgãos de contato nas escamas do flanco, 34-35 vértebras, ausência de dentes no vomer e presença de séries transversais de escamas na base da nadadeira anal.

Key words: Taxonomy, Systematics, Bioacustics, Etology, Sexual behavior.

\section{Introduction}

The killifish genus Cynolebias Steindachner, 1876 comprises species living in seasonal lagoons and pools of central and northeastern Brazil (Costa, 2001). A single species, C. griseus Costa, Lacerda \& Brasil, 1990, is endemic to a Cerrado area in the upper Tocantins River basin, central Brazil, while other 12 species are uniquely found in the Caatinga of northeastern Brazil (Costa, 2001; Costa et al., 2007). The species from the Caatinga are recorded from a wide zone of northeastern Brazil, include C. albipunctatus Costa \& Brasil, 1991, C. altus Costa, 2001, C. attenuatus Costa, 2001, C. gibbus Costa, 2001, C. gilbertoi Costa, 1998, C. leptocephalus Costa \& Brasil, 1993, and C. perforatus Costa \& Brasil, 1991, from the São Francisco River basin; C. porosus Steindachner, 1876, C. vazabarrisensis Costa, 2001, C. itapicuruensis Costa, 2001, and C. paraguassuensis, Costa, Suzart \& Nielsen, 2007, from smaller river basins draining to east; $C$. microphthalmus Costa $\&$ Brasil, 1995, from the Jaguaribe and smaller river basins draining to north (Costa, 2001; Costa et al., 2007).

All species endemic to the Caatinga form the wellsupported clade a (Costa, 2001), diagnosed by apomorphic character states of the jaw suspensorium, branchial arches, neurocranium, shoulder girdle and laterosensory system (Costa, 2001, 2009). Seven diagnostic apomorphic character states refer to unique morphological structures concentrated in the pharyngeal jaw apparatus (PJA): anterior portion of the fifth ceratobranchial narrow and long; robust teeth on the

${ }^{1}$ Laboratório de Sistemática e Evolução de Peixes Teleósteos, Departamento de Zoologia, Universidade Federal do Rio de Janeiro. Caixa Postal 68049, 21944-970 Rio de Janeiro, RJ, Brazil.wcosta@biologia.ufrj.br, lu_castanha@yahoo.com.br.

${ }^{2}$ Laboratório de Sistemática e Morfologia de Peixes, Departamento de Sistemática e Ecologia, Universidade Federal da Paraíba. Cidade Universitária, 58059-900 João Pessoa, PB, Brazil.telton@gmail.com, robtamar@gmail.com. 
second pharyngobranchial and fifth ceratobranchial; a pronounced process on the ventral surface of the fifth ceratobranchial; fifth ceratobranchials medially in contact; infrabranchial ossification; fourth epibranchial L-shaped and with a process for insertion of the levator posterior muscle; third and fourth levator externi and protractor pectoralis widened to make levator posterior not visible laterally (Costa, 2001, 2009). The specialized PJA of the clade a is supposedly related to the sound production made by males during the courtship behavior reported for C. albipunctatus (Belote \& Costa, 2003; Costa, 2009), which constitutes a unique behavior among cyprinodontiform fishes. However, sound production was never recorded in Cynolebias (Belote \& Costa, 2003). The objective of the present study is to describe a new species of the Cynolebias clade a, including a first description of sound production.

\section{Material and Methods}

Specimens were fixed in formalin for a period of 10 days, and then transferred to $70 \%$ ethanol, except two specimens, one male and one female (UFRJ 6736), kept alive for behavior studies, and there after directly fixed in ethanol $95 \%$. Material is deposited in the ichthyological collections of the Instituto de Biologia, Universidade Federal do Rio de Janeiro, Rio de Janeiro (UFRJ), and Departamento de Sistemática e Ecologia, Universidade Federal da Paraíba, João Pessoa (UFPB). Descriptions of color pattern were based on photographs of live type individuals taken in aquaria after collection. Measurements and counts follow Costa (1995). Measurements are presented as percents of standard (SL) or head length. Meristic data range included all specimens available for study. Fin-ray counts include all elements. Number of vertebrae and gill-rakers were recorded from cleared and stained specimens; the compound caudal centrum was counted as a single element. Osteological preparations were made according to Taylor \& van Dyke (1985). Terminology for bones follows Costa (2006), for frontal squamation Hoedeman (1958) and for cephalic neuromast series Costa (2001). Delimitation of species follows the methodology of the Population Aggregation Analysis (Davis \& Nixon, 1992)

Recordings of reproductive behavior were obtained in aquaria. The two specimens were kept separately in aquaria sizing $30 \times 20 \times 20 \mathrm{~cm}$ until the female was placed in the male aquarium which contained coir fiber as substrate. The behavior patterns were observed at least seven times, in a total of 15 recording hours. The visual recordings were made with Panasonic SDR-H40 Digital Camcorder. The acoustic recordings were made with Cetacean Research C54XRS hydrophone and M-AUDIO MicroTrack II Professional 2 Channel Mobile Digital Recorder. The hydrophone filter bandwidth utilized was $20 \mathrm{~Hz}$. The sounds were recorded at a sample rate $48 \mathrm{kHz}$ and sample size of 24 bits. The sounds were analyzed with the software Raven Pro 1.3 from Cornell Laboratory of Ornithology (Bioacoustics Research Program).
Sounds produced during Cynolebias courtship behavior were identified as thumps, following Rowland (1978). The acoustic measured parameters were: thump duration, repetition rate of thumps per courtship, duration of interthumps intervals, dominant frequency and frequency bandwidth of thump. Occasional thumps off the courtship were not utilized in measurements as repetition rate of thumps per courtship and duration of interthumps intervals. Numerical acoustic parameters are given as range followed by mean \pm SD in parenthesis. The temporal parameters were measured directly from the oscilograms and frequency parameters were measured directly from the spectrograms. All recordings were deposited in the Arquivo Sonoro Professor Elias Coelho (ASEC), Laboratório de Bioacústica, Instituto de Biologia, Universidade Federal do Rio de Janeiro, Rio de Janeiro (recordings ASEC 14826 to 14832).

\section{Cynolebias parnaibensis, new species Fig. 1}

Holotype. UFPB 6719, 54.5 mm SL, male, Brazil, Estado do Piauí, Município de Jacobina do Piauí, seasonal lagoon at the right side of the road between Conceição do Canindé and Jacobina do Piauí, 0800'54"S 41²5’26"W, 19 May 2009, T. Ramos, M. Silva \& J. Aparecido.

Paratypes. UFPB 6709, 39.0-46.2 mm SL, 6 females, UFRJ 6734, 44.3-45.9 mm SL, 2 females; UFRJ 6735, 51.7 mm SL, 1 male, 41.5-41.8 mm SL, 2 females (cleared and stained for bone), collected with holotype. UFRJ 6736, $50.2 \mathrm{~mm}$ SL, 1 male, $41.8 \mathrm{~mm} \mathrm{SL}, 1$ female, same locality as holotype, 28 June 2009, T. Ramos, P. Honório \& A. Carvalho.

Diagnosis. Cynolebias parnaibensis is distinguished from all other species of the genus, except C. griseus and C. gilbertoi, by having 27-31 neuromasts around eye (vs. 33-46). The new species differs from $C$. griseus by having 29-33 supraorbital neuromasts ( $v s .19-22), 16-18$ dorsal-fin rays and 19 anal-fin rays in males (vs. 20-22 and 21-23, respectively), 28-31 caudalfin rays ( $v s .33-34), 6$ pelvic-fin rays ( $v s .5$ ), dorsal-fin origin at a vertical between the base of the 4th or 6th anal-fin ray ( $v s$. base of 1st or 2nd ray), 33-36 scales in the longitudinal series (vs. 29$31), 3+10$ gill-rakers in the first branchial arch (vs. 5+15), absence of second pharyngobranchial teeth ( $v s$. presence), absence of the ventral uncinate process of the second epibranchial ( $v s$. presence), absence of the ventral limb of the posttemporal ( $v s$. presence), and absence of contact organs on the flank scales in both sexes ( $v s$. presence in males). From $C$. gilbertoi it differs by having 34-35 vertebrae (vs. 32-33), and by the absence of teeth on vomer (vs. 13-15 vomerine teeth). Cynolebias parnaibensis is also distinguished from C. griseus, C. gilbertoi, C. microphthalmus and C. albipunctatus by the presence of transverse series of scales on the anal-fin base ( $v s$. absence).

Description. Morphometric data in Table 1. Dorsal and ventral profiles convex between snout and anterior part of caudal peduncle, nearly straight on caudal peduncle. Body moderately deep, slightly compressed, greatest body depth 


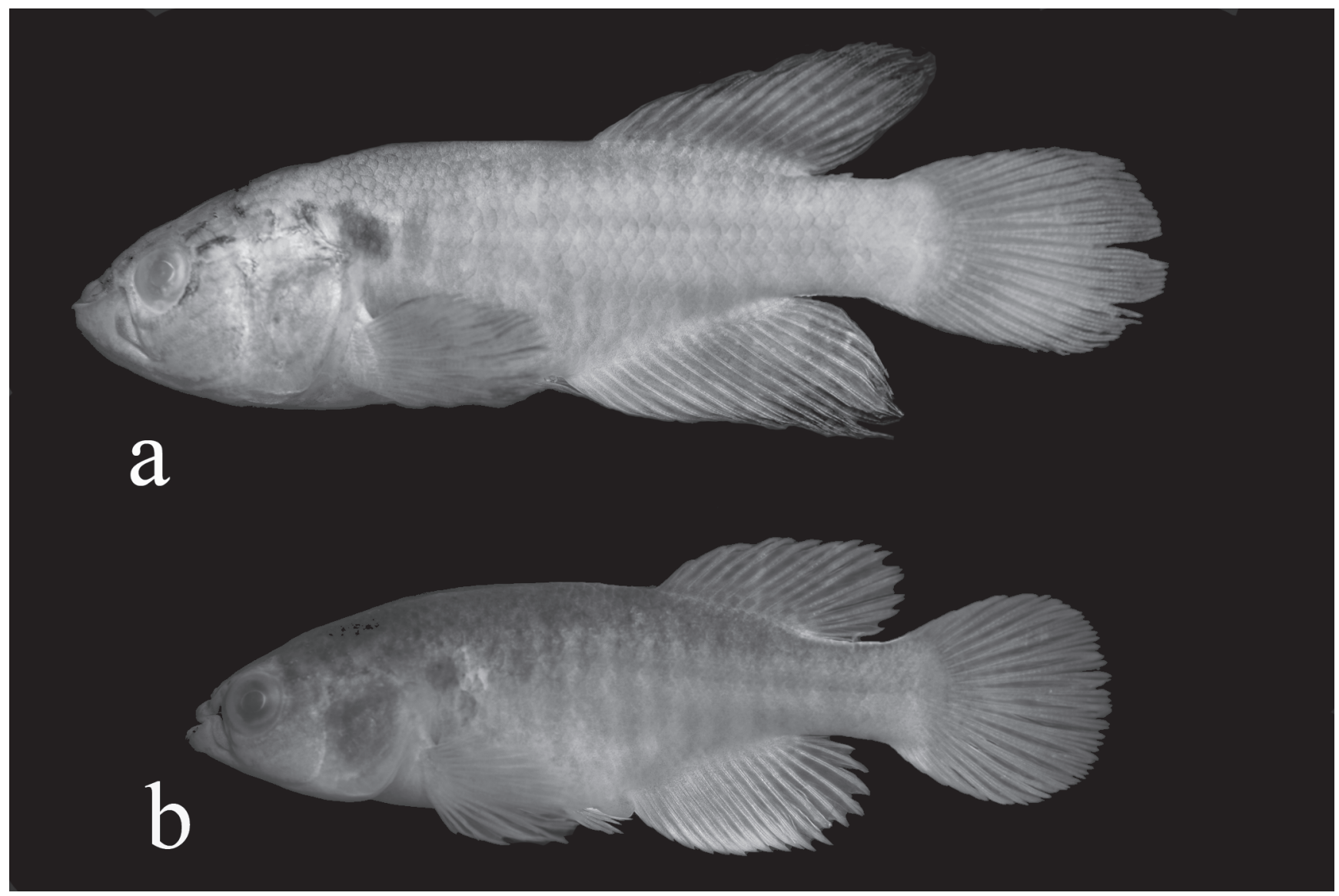

Fig. 1. Cynolebias parnaibensis, Jacobina do Piauí, Piauí, Brazil. (a) UFPB 6719, holotype, male, 54.5 mm SL. (b) UFPB 6709, paratype, female, $46.2 \mathrm{~mm} \mathrm{SL}$.

at level of vertical just anterior to pelvic-fin base. Snout short, blunt.

Dorsal and anal fins pointed in males, rounded in females. Pectoral fin long, rounded, reaching vertical between base of 2nd and 4 th anal-fin rays in males, and between pelvic-fin base and anus in females. Tip of pelvic fin reaching between

Table 1. Morphometric data of Cynolebias parnaibensis.

\begin{tabular}{lccc}
\hline & Holotype & \multicolumn{2}{c}{ Paratypes } \\
& Male & Male $(\mathrm{n}=1)$ & Females $(\mathrm{n}=8)$ \\
\hline Standard length (mm) & 54.5 & 51.7 & $40.8-46.2$ \\
& Percents of standard length & \\
Body depth & 31.2 & 32.8 & $30.5-33.6$ \\
Caudal peduncle depth & 14.1 & 14.7 & $12.9-13.9$ \\
Predorsal length & 61.8 & 64.2 & $63.8-66.8$ \\
Prepelvic length & 51.5 & 52.1 & $52.9-56.5$ \\
Length of dorsal-fin base & 26.5 & 25.5 & $21.3-23.7$ \\
Length of anal-fin base & 30.3 & 30.8 & $24.2-27.0$ \\
Caudal-fin length & 33.0 & 35.3 & $31.7-33.6$ \\
Pectoral-fin length & 24.9 & 24.8 & $23.0-26.2$ \\
Pelvic-fin length & 9.6 & 9.1 & $9.2-10.7$ \\
Head length & 31.2 & 31.2 & $30.6-32.5$ \\
& Percents of head length & \\
Head depth & 93.0 & 93.0 & $84.3-91.7$ \\
Head width & 74.4 & 74.9 & $72.7-77.4$ \\
Snout length & 14.4 & 14.1 & $13.3-14.9$ \\
Lower jaw length & 27.4 & 24.1 & $20.0-23.4$ \\
Eye diameter & 24.2 & 27.7 & $29.2-32.4$ \\
\hline
\end{tabular}

base of 2nd and 3rd anal-fin rays in males, reaching between urogenital papilla and anal-fin origin in females. Pelvic-fin bases medially separated by small interspace. Dorsal-fin origin through base of 5th or 6th anal-fin ray in males, and above base of 4th or 5th anal-fin ray in females; dorsal-fin origin between neural spines of vertebrae 15 and 17 in both sexes. Anal-fin origin between pleural ribs of vertebrae 11 and 12 in males, and pleural ribs of vertebrae 13 and 14 in females. Dorsal-fin rays 16-18 in males, 15-16 in females; anal-fin rays 19 in males, 18-21 in females; caudal-fin rays 28-31; pectoralfin rays 13-14; pelvic-fin rays 6 .

Frontal scales irregularly arranged; 11-12 small supraorbital scales. Longitudinal series of scales 33-36; transverse series of scales 14-16; scale rows around caudal peduncle 22. No contact organ on flank. Minute papillate contact organs on inner surface of upper six pectoral fin-rays in males. No contact organs on pelvic and unpaired fins.

Cephalic neuromasts: supraorbital 29-33, parietal 3-4, anterior rostral 3, posterior rostral 3, infraorbital 4+27-31, preorbital 3, otic 6-7, post-otic 7, supratemporal 3, median opercular 2, ventral opercular 3-5, preopercular plus mandibular 44-53, lateral mandibular 9-10, paramandibular 1. One neuromast on each scale of lateral line. Two neuromasts on caudal-fin base. 
Basihyal subtriangular, width about $60 \%$ of length; basihyal cartilage about $20 \%$ of total length of basihyal. Six branchiostegal rays. Second pharyngobranchial teeth absent. Gill-rakers on first branchial arch 3+10. Vomerine teeth absent. Dermosphenotic absent. Ventral process of posttemporal absent. Total vertebrae 34-35.

Coloration. Males. Side of body light pinkish brown, with narrow pale golden bars; bluish white dots on whole flank; one or two rounded, pale greenish gray humeral blotches. Venter light orangish yellow. Head side yellowish gray, pale golden on opercular region; small dark reddish brown spots along laterosensory series of neuromasts around orbit and on postorbital region. Iris orangish yellow with dark reddish brown bar through center of eye. Unpaired fins yellowish gray on basal and central portions, to pale gray on distal part of dorsal and caudal fins, and pale orange on distal portion of anal fin. Pectoral fin hyaline. Pelvic fin pale orange.

Females. Side of body purplish gray, with narrow pale golden bars; one or two rounded, pale greenish gray humeral blotches; sometimes, rounded black blotch on anterocentral portion of flank. Venter light gray. Head side yellowish gray, pale golden on opercular region; small dark reddish brown spots along laterosensory series of neuromasts around orbit and on postorbital region. Iris orangish yellow with dark reddish brown bar through center of eye. Unpaired fins light gray with faint light gray dots. Paired fins hyaline.

Courtship behavior. Just after induced meetings, the male stays near the bottom whereas the female continuously and slowly swims through the aquarium. This period, herein named as adaptation period, lasted approximately $30 \mathrm{~min}$. After the adaptation period, the courtship begins by the male, which perform a quick and discontinuous swimming towards female. Following the female approximation, the male shakes the head up and downwards producing sound (see sound description below). Just after sound is produced, the female readily starts to swim around male, often scrubbing its snout on the ventral surface of the male trunk, mainly around the genital region. The male swims near the substrate always followed and scrubbed by the female. The male put its snout down into the substrate, in a vertical position, quivering body and fins, which is similar to the stage named as invitation to submerge, described by Belote \& Costa (2003) for C. albipunctatus. The time between start of courtship and the invitation to submerge lasted approximately $60 \mathrm{~min}$. Spawning and fertilization were not observed.

Sound. Head shaking male display was synchronized with sound production. The sound consists of a single pulse as a thump. The thump duration ranges from $0.031 \mathrm{~s}$ to $0.133 \mathrm{~s}(\mathrm{~m}=$ $0.081 \mathrm{~s} ; \mathrm{sd}=0.024 ; \mathrm{n}=123)$. Duration of interthump intervals ranges from $0.020 \mathrm{~s}$ to $8.319 \mathrm{~s}(\mathrm{~m}=0.748 ; \mathrm{sd}=1.061 ; \mathrm{n}=122)$. Repetition rate of thumps per courtship ranges from 0.995 to 1.026 thumps per second $(\mathrm{m}=1.011 ; \mathrm{sd}=0.022 ; \mathrm{n}=2)$. Dominant frequency varied between 70.3 and $93.8 \mathrm{~Hz}(\mathrm{~m}=$
$78.5 ; \mathrm{sd}=11.3 ; \mathrm{n}=83$ ), although in some thumps the values of dominant frequency were 46.9 and $23.4 \mathrm{~Hz}$. These last values are the dominant frequency of background noise, thus these measured values are possibibly due to the low intensity of some thumps. The frequency bandwidth of each thump is from near to zero to $1 \mathrm{kHz}$ (Fig. 2). There were occasional thumps off the courtship during the adaptation period. Moments with high repetition rate of thumps were observed when the male apparently was more excited.

Distribution and habitat. Cynolebias parnaibensis is known from the type locality, a seasonal lagoon close to the road between Conceição de Canindé and Jacobina do Piauí, Município de Jacobina do Piauí, Piauí State, northeastern Brazil. The type locality is inserted in the Caatinga domain, a semi-arid phytogeographic formation, typical of northeastern Brazil. The lagoon is within the Canindé River drainage, which is part of the Parnaíba River basin. It was about $60 \mathrm{~m}$ long, $15 \mathrm{~m}$ wide, maximum depth $1 \mathrm{~m}$, average depth $50 \mathrm{~cm}$. The water was turbid, light brown, and the bottom was sandy-muddy. Emerging aquatic vegetation occurred in moderate amount, scattered over the lagoon surface, while large amount of submerged vegetation was found, predominating species of the family Hydrocharitaceae. Margins of the pond were in part densely covered by bushes and low vegetation.

Etymology. The name parnaibensis is a reference to the unique occurrence in the Parnaíba River basin among species of the genus Cynolebias.

\section{Discussion}

Cynolebias parnaibensis is a member of the clade a (Costa, 2001), exhibiting all derived character states of the PJA used to diagnose the clade (see Introduction above). In addition, sound production tentatively recorded in a previous study only for C. albipunctatus (Belote \& Costa, 2003), but hypothesized to occur in all species of the clade a (Costa, 2009), is herein confirmed for C. paranaibensis.

The combination of the diagnostic character states described for $C$. parnaibensis does not provide unambiguous evidence for its phylogenetic position among congeners. Among species of the clade a, C. parnaibensis shares with $C$. altus, $C$. attenuatus, $C$. gibbus, $C$. leptocephalus, $C$. perforatus, $C$. porosus, $C$. vazabarrisensis, C. itapicuruensis and C. paraguassuensis the presence of transverse rows of scales on the anal-fin base in males. This condition is not present in three species of the clade a, C. albipunctatus, C. gilbertoi and $C$. microphthalmus, in which the flank scales just slightly project on the middle portion of the anal-fin base, a condition similar to that found in most species of Simpsonichthys (Costa, 2006, 2007). The presence of transverse rows of scales on the anal-fin base was considered by Costa (2001) as a synapomorphy of a clade containing some species 


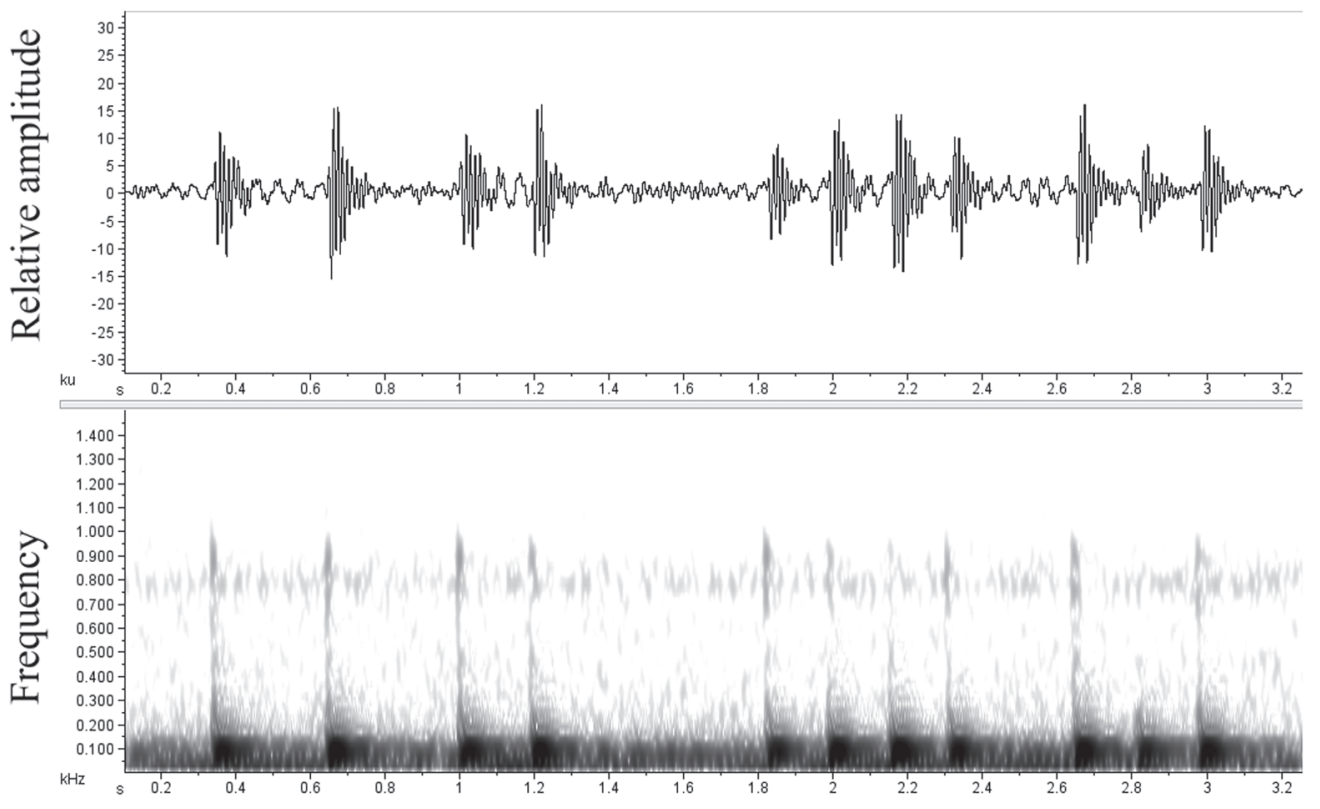

a

Time

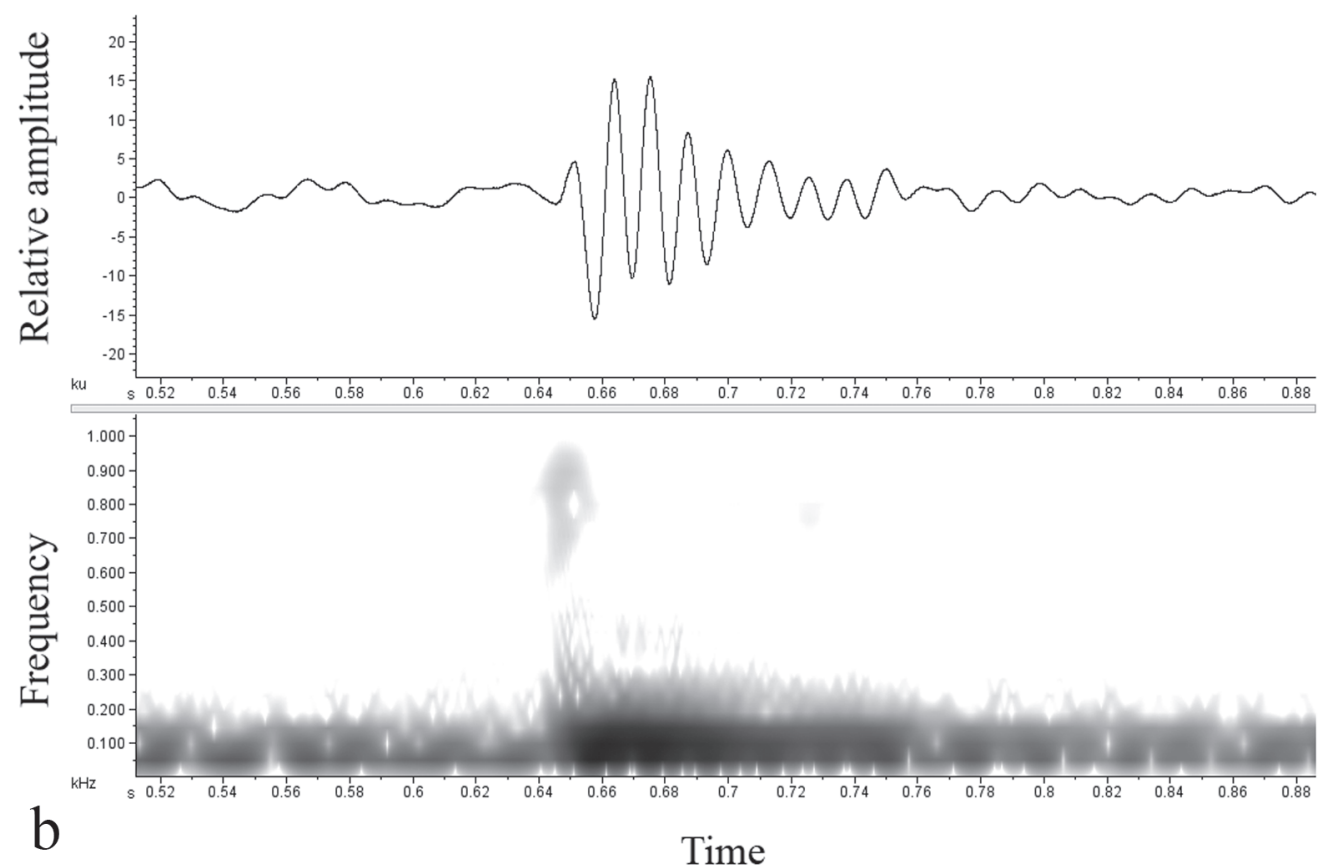

Fig. 2. General thump sequence produced by the male of Cynolebias parnaibensis during the courtship behavior (a), and a single thump expanded (the second one above) (b). Oscilogram above and spectogram below (window function Hann, overlap $99 \%$, FFT size 1,200 points).

endemic from the middle São Francisco basin (C. altus, $C$. attenuatus, C. gibbus, C. leptocephalus, C.perforatus) and all species from smaller eastern river basins (C. porosus, $C$. vazabarrisensis, C. itapicuruensis, C. paraguassuensis). Thus, the presence of that apomorphic condition for analfin base squamation in C. parnaibensis suggests that it is part of that clade. In contrast, the presence of relatively few neuromasts in the supraorbital and infraorbital of $C$. parnaibensis, considered plesiomorphic by Costa (2001), suggests a more basal phylogenetic position of the new species. Therefore, the character states here discussed are useful to diagnose the new species, but are not effective to erect hypotheses of phylogenetic relationships, which is not an objective of the present paper. 


\section{Acknowledgements}

We are grateful to J. Aparecido, A. Carvalho, P. Honório and M. Silva for help in the collecting trips; to L. A. P. Gonzaga for support at Laboratório de Bioacústica, UFRJ; to F. S. F. S. Hepp for reviewing the bioacoustics text; and, to O. Afonso and C. Luna-Dias for technical assistance. This study was supported by CNPq (Conselho Nacional de Desenvolvimento Científico e Tecnológico - Ministério de Ciência e Tecnologia) through grants to WJEMC and TPAR and FAPERJ (Fundação de Amparo à Pesquisa do Estado do Rio de Janeiro) through grants to WJEMC and LCA. Material was collected with permits from IBAMA (20088-2 SISBIO).

\section{Literature Cited}

Belote, D. F. \& W. J. E. M. Costa. 2003. Reproductive behavior of the Brazilian annual fish Cynolebias albipunctatus Costa \& Brasil, 1991 (Teleostei, Cyprinodontiformes, Rivulidae): a new report of sound production in fishes. Arquivos do Museu Nacional, 61: 241-244.

Costa, W. J. E. M. 1995. Pearl killifishes - the Cynolebiatinae: systematics and biogeography of the neotropical annual fish subfamily. TFH, Neptune City, 128p.

Costa, W. J. E. M. 2001. The neotropical annual fish genus Cynolebias (Cyprinodontiformes: Rivulidae): phylogenetic relationships, taxonomic revision and biogeography. Ichthyological Exploration of Freshwaters, 12: 333-383.

Costa, W. J. E. M. 2006. Descriptive morphology and phylogenetic relationships among species of the Neotropical annual killifish genera Nematolebias and Simpsonichthys (Cyprinodontiformes: Aplocheiloidei: Rivulidae). Neotropical Ichthyology, 4: 1-26.

Costa, W. J. E. M. 2007. Taxonomic revision of the seasonal South American killifish genus Simpsonichthys (Teleostei: Cyprinodontiformes: Aplocheiloidei). Zootaxa, 1669: 1-134.

Costa, W. J. E. M. 2009. Morphology of the teleost pharyngeal jaw apparatus in the Neotropical annual killifish genus Cynolebias (Cyprinodontiformes: Aplocheiloidei: Rivulidae). Cybium, 33: 145-150.

Costa, W. J. E. M., R. Suzart \& D. T. B. Nielsen. 2007. Cynolebias paraguassuensis n. sp. (Teleostei: Cyprinodontiformes: Rivulidae), a new seasonal killifish from the Brazilian Caatinga, Paraguaçu River basin. Aqua International Journal of Ichthyology, 12: 129-132.

Davis, J. I. \& K. C. Nixon. 1992. Populations, genetic variation, and the delimitation of phylogenetic species. Systematic Biology, 41: 421-435.

Hoedeman, J. J. 1958. The frontal scalation pattern in some groups of toothcarps (Pisces, Cyprinodontiformes). Bulletin of Aquatic Biology, 1: 23-28.

Rowland, W. J. 1978. Sound production and Associate behavior in the jewel fish, Hemichromis bimaculatus. Behavior, 64: 125-136.

Taylor, W. R. \& G. C. van Dyke. 1985. Revised procedures for staining and clearing small fishes and other vertebrates for bone and cartilage study. Cybium, 9: 107-109.

Accepted February 27, 2010

Published June 25, 2010 